\title{
Human T-lymphotropic virus type 1 (HTLV-1) and cellular immune response in HTLV-1-associated myelopathy/tropical spastic paraparesis
}

\author{
Satoshi Nozuma ${ }^{1} \cdot$ Ryuji Kubota $^{2} \cdot$ Steven Jacobson $^{1}$ \\ Received: 29 March 2020 / Revised: 29 March 2020 / Accepted: 6 July 2020 / Published online: 23 July 2020 \\ (C) The Author(s) 2020
}

\begin{abstract}
Human T-lymphotropic virus type 1 (HTLV-1) is associated with adult T cell leukemia/lymphoma and HTLV-1-associated myelopathy/tropical spastic paraparesis (HAM/TSP). HAM/TSP is an inflammatory disease of the spinal cord and clinically characterized by progressive spastic paraparesis, urinary incontinence, and mild sensory disturbance. The interaction between the host immune response and HTLV-1-infected cells regulates the development of HAM/TSP. HTLV-1 preferentially infects CD4 ${ }^{+}$ $\mathrm{T}$ cells and is maintained by proliferation of the infected T cells. HTLV-1-infected cells rarely express viral antigens in vivo; however, they easily express the antigens after short-term culture. Therefore, such virus-expressing cells may lead to activation and expansion of antigen-specific T cell responses. Infected T cells with HTLV-1 and HTLV-1-specific CD8 ${ }^{+}$cytotoxic T lymphocytes invade the central nervous system and produce various proinflammatory cytokines and chemokines, leading to neuronal damage and degeneration. Therefore, cellular immune responses to HTLV-1 have been considered to play important roles in disease development of HAM/TSP. Recent studies have clarified the viral strategy for persistence in the host through genetic and epigenetic changes by HTLV-1 and host immune responses including T cell function and differentiation. Newly developed animal models could provide the opportunity to uncover the precise pathogenesis and development of clinically effective treatment. Several molecular target drugs are undergoing clinical trials with promising efficacy. In this review, we summarize recent advances in the immunopathogenesis of HAM/TSP and discuss the perspectives of the research on this disease.
\end{abstract}

Keywords HTLV-1 $\cdot \mathrm{HAM} / \mathrm{TSP} \cdot$ Neurological disorders $\cdot$ Immunology $\cdot$ Pathogenesis

\section{Introduction}

Human T-lymphotropic virus type 1 (HTLV-1) is the human retrovirus firstly discovered in 1980 (Poiesz et al. 1980). The main highly endemic areas are the Southwestern part of Japan, the Caribbean, South America, Central and Southern Africa, Middle East, and Central Australia. It is estimated that at least five to ten million people are infected with HTLV-1, but the current number of HTLV-1 carries might be much higher due to a lack of systematic epidemiological studies in most

Steven Jacobson

jacobsons@ninds.nih.gov

1 Viral Immunology Section, Division of Neuroimmunology and Neurovirology, National Institute of Neurological Disorders and Stroke, National Institutes of Health, Bethesda, MD, USA

2 Division of Neuroimmunology, Joint Research Center for Human Retrovirus Infection, Kagoshima University, Kagoshima, Japan endemic regions (Gessain and Cassar 2012). For example, it recently reported that more than $40 \%$ of central Australian Indigenous adults in some remote communities are HTLV1c infected (Einsiedel et al. 2016). While the majority of infected individuals remain lifelong asymptomatic carriers (ACs), approximately 2-5\% develop adult T cell leukemia/ lymphoma (ATLL) (Uchiyama et al. 1977) and another 0.25 $3.8 \%$ develop HTLV-1-associated myelopathy/tropical spastic paraparesis (HAM/TSP) (Gessain et al. 1985; Osame et al. 1986). HTLV-1 has also been associated with other inflammatory diseases including uveitis, myositis, infective dermatitis, and interstitial pneumonitis (Gessain and Mahieux 2012). HAM/TSP is clinically characterized by chronic progressive spastic paraparesis, urinary incontinence, and mild sensory disturbance. HTLV-1 preferentially infects $\mathrm{CD} 4^{+} \mathrm{CD} 25^{+} \mathrm{T}$ cells in vivo and induces functional changes in the infected cells. HTLV-1-infected cells rarely express viral antigens in vivo; however, they easily express antigens after shortterm culture. Therefore, such virus-expressing cells may lead 
to activation and expansion of antigen-specific $\mathrm{T}$ cell responses. The virus-host immunologic interaction plays a pivotal role in the pathogenesis of HAM/TSP. HTLV-1-infected $\mathrm{T}$ cells and $\mathrm{CD} 8^{+}$cytotoxic $\mathrm{T}$ lymphocytes (CTL) against HTLV-1 invade the central nervous system (CNS) and release proinflammatory cytokines and chemokines, resulting in the tissue damage. These immune responses are considered to underlie the pathogenesis of HAMTSP. Both HTLV-1 viral regulatory proteins, Tax and HTLV-1 basic leucine zipper factor (HBZ), play critical roles in immune dysregulation in HAM/TSP (Enose-Akahata et al. 2017). Tax induces the expression of many host cellular genes and consequently contributes to cell activation and proliferation. HBZ induces inflammation in the host through altering the Foxp3 expression in Treg cells (Satou et al. 2011; Yamamoto-Taguchi et al. 2013). Although HAM/TSP is not directly life-threatening, the disease severely impacts patients' quality of life (Olindo et al. 2006; Coler-Reilly et al. 2016), and treatment remains highly unsatisfactory. Humanized mice models were developed and could be potential novel tools for understanding HTLV-1 neuropathogenesis and testing of novel therapies for HAM/TSP. Several trials for new drugs have been performed and show promising results. Here, we summarize the immunopathology of HAM/TSP, specifically focused on cellmediated immunity in this disease and discuss ongoing developments and perspectives of HAM/TSP research.

\section{HTLV-1 virus}

HTLV-1 belongs to the Deltaretrovirus genus of the Orthoretrovirinae subfamily of retroviruses. Most HTLV-1infected $\mathrm{T}$ cells contain a single integrated provirus (Cook et al. 2012). The HTLV-1 proviral genome is $9 \mathrm{~kb}$ in length and contains structural genes, gag, pol, and env flanked by a long terminal repeat at both the $5^{\prime}$ and $3^{\prime}$ ends. The HTLV-1 genome also has a $p X$ region including six open reading frames: five on the plus-strand and one on the minus-strand. Of these six genes, tax, rex, and $H B Z$ play a key role in the infectivity and proliferation of HTLV-1. Other regulatory genes $p 8, p 12, p 13$, and $p 30$ are expressed at very low levels and these proteins are considered to have minor roles in replication and persistence of HTLV-1 in vivo (Bangham 2018). HTLV-1 can be transmitted through intravenous drug use, sexual contact, and breastfeeding from mother to child. Familial clusters of HAM/TSP were reported (Nozuma et al. 2014; Alvarez et al. 2016), but genetic analysis of host genomes was not able to detect any disease-associated genes due to a small number of cases (Nozuma et al. 2017). HTLV-1 has remarkably low genetic variability both within and between hosts, although minor variations exist between geographical isolates (Komurian et al. 1991). Most studies of HTLV-1 genotype have reported no correlation between nucleotide substitutions and the risk of HAM/TSP (Mahieux et al. 1995), and the recent analysis of complete HTLV-1 sequence could not detect any HAM/TSP-specific mutations (Pessoa et al. 2014; Nozuma et al. 2017). However, the transcontinental HTLV-1 subtype is associated with an increased risk of HAM/TSP compared with the Japanese subtype in the Japanese population (Furukawa et al. 2000; Saito 2019). HAM/TSP patients with transcontinental subtype showed lower levels of $H B Z$ mRNA expression (Yasuma et al. 2016a) and higher levels of CXCL10, which has been proposed to be a prognostic biomarker for HAM/TSP (Naito et al. 2018). A recent study showed that CTCF, a master regulator of chromatin structure and expression, bound to HTLV-1 and formed loops between proviral and host genomes to regulate the expression of proviral and host genes (Satou et al. 2016). Epigenetic modifications may regulate the pattern of proviral transcription and mediate inflammation in HAM/TSP patients, and further studies are necessary to clarify the role of these mechanisms in the pathogenesis of HAM/TSP.

\section{Molecular pathogenesis of Tax}

The tax gene encodes a 353-amino acid, 40-kDa protein, Tax, that has a central role in HTLV-1 biology (Bangham 2018). HTLV-1 Tax is a transcriptional transactivator of virus replication and induces the expression of a variety of cellular genes by activation of the NF-KB and CREB/ATF pathways (Matsuoka and Jeang 2011). De novo infection requires expression of Tax since transcription of the sense-strand of the provirus which is responsible for the generation of the viral genome and viral proteins. Tax has been extensively studied because it induces the expression of many host cellular genes and consequently contributes to dysfunction in immune cells of HAM/TSP patients. Ex vivo, Tax protein is spontaneously expressed in peripheral blood mononuclear cells (PBMCs) after culture without any exogenous stimulation (Hanon et al. 2000a) and the level of tax mRNA was significantly higher in HAM/TSP patients than in ACs (Yamano et al. 2002). Tax boosts expression of $T$ box transcription factor (T-bet), which promotes IFN- $\gamma$ production (Araya et al. 2014). A number of the common $\gamma$ chain family of cytokines and their receptors, such as IL-2/IL-2R, IL-9, IL-15/IL-15R, and IL-21/IL-21R have been demonstrated to be transactivated by Tax (Enose-Akahata et al. 2017).

Tax is an immunodominant antigen recognized by HTLV1-specific cytotoxic CD8 ${ }^{+} \mathrm{T}$ cells (Jacobson et al. 1990). The number of Tax-specific CTL is greatly elevated and these CTL produce proinflammatory cytokines (Kubota et al. 1998) and show degranulation activity in HAM/TSP patients that is comparable with that in ACs (Abdelbary et al. 2011). Though Tax protein is usually undetected in vivo, recent analysis shows that it is expressed in intermittent but intense bursts at the single-cell level by the observation of HTLV-1-infected 
cell lines (Billman et al. 2017; Mahgoub et al. 2018). Therefore, Tax-specific immune responses are chronically activated and might be pathogenic, rather than protective, due to high cytotoxicity and the production of inflammatory cytokines leading to neural damage.

\section{Molecular pathogenesis and localization of HBZ}

HBZ was first discovered in 2002 as a novel viral protein that contains an $\mathrm{N}$-terminal transcription activation domain and a leucine zipper motif in its C-terminus (Gaudray et al. 2002). As HBZ closely cooperates with Tax, HBZ has opposing functions to Tax and modifies transcription of various host genes (Matsuoka and Jeang 2011). HBZ is persistently expressed in infected cells, maintains viral latency (Philip et al. 2014), and promotes proliferation of ATLL cells (Satou et al. 2006; Arnold et al. 2008), whereas Tax expression is frequently silenced. HBZ interacts with CREB/ATF pathway, suppresses Tax-mediated transactivation, and selectively inhibits the classical NF-KB pathway (Matsuoka and Jeang 2011). HBZ interacts with the tumor suppressor $\mathrm{Rb}$, and promotes proliferation of infected cells and counteracts apoptosis through HBZ-induced expression of survivin (Kawatsuki et al. 2016). In HBZ-Tg mice, HBZ increases the number of $\mathrm{CD} 4^{+} \mathrm{Foxp}^{+}{ }^{+}$Treg cells and then converts them to Foxp $3^{-} \mathrm{T}$ cells with producing IFN- $\gamma$, which results in inflammation and tumors (Satou et al. 2011; YamamotoTaguchi et al. 2013). HBZ has been recently recognized to play a critical role in inflammation and pathogenesis of HAM/TSP. The level of $H B Z$ mRNA detected in HAM/TSP patients is significantly lower than in ATLL patients but higher than in ACs. Furthermore, $H B Z$ mRNA expression was associated with HTLV-1 proviral load and increased disease severity in HAM/TSP patients (Saito et al. 2009). Antibody response against HBZ was observed in HTLV-1infected subjects and related to decreased $\mathrm{CD}^{+} \mathrm{T}$ cell activation in HAM/TSP patients (Enose-Akahata et al. 2013). HBZ is also an immunogenic protein recognized by HBZ-specific CTL clones; however, HBZ is regarded as a weaker immunogen for CTL than Tax. HBZ-specific CTL clones could not lyse ATLL cells (Suemori et al. 2009) and killed significantly fewer infected cells than were killed by Tax-specific CTL clones (Rowan et al. 2014). The weaker immunogenicity of HBZ could, therefore, allow HTLV-1-infected cells to escape from the host immune response.

HBZ contains nuclear localization signals in its central/ bZIP domain and nuclear export signals in its $\mathrm{N}$-terminus (Hivin et al. 2005). HBZ is found in the nucleus in leukemic cells and the function of nuclear HBZ has been thoroughly investigated and reported to interact with important transcription factors including $\mathrm{CBP} / \mathrm{p} 300, \operatorname{Smad} 3, \mathrm{p} 65$, c-Jun, and forkhead family proteins especially in ATLL (Tanaka and Matsuoka 2018). However, HBZ protein has been recently reported to be localized in the cytoplasm of T cells depending on the expression of THEMIS (Kinosada et al. 2017). HBZ interferes with the complex formation of THEMIS with Grb2 and SHP-2, which results in inhibition of the suppressive functions of coinhibitory receptors TIGIT and PD-1, and subsequently might enhance activation of T cells. In HAM/TSP patients, HBZ is reported to localize exclusively in the cytoplasm of infected cells and the number of HBZ-positive cells is higher in HAM/TSP patients compared with ACs (Baratella et al. 2017; Forlani et al. 2019). Cytoplasmic HBZ was almost exclusively found in the $\mathrm{CD} 4^{+} \mathrm{T}$ cell without coexpression of CD25 and the coexpression of HBZ and Tax was rarely found in the same cell. Distinct subcellular compartments of HBZ might therefore be associated with different pathogenetic mechanisms observed in ATLL and HAM/TSP.

\section{HTLV-1-infected T cells}

HTLV-1 preferentially infects $\mathrm{CD} 4^{+} \mathrm{T}$ cells in vivo and induces functional changes in the infected cells (Enose-Akahata et al. 2017; Yamano and Coler-Reilly 2017). An elevated HTLV-1 proviral load (PVL) is the main risk factor for developing HAM/TSP in HTLV-1-infected subjects and is strongly associated with disease pathogenesis (Nagai et al. 1998; Nagai et al. 2001). The receptors for HTLV-1 have been reported to involve HTLV-1 entry and include glucose transporter 1, neuropilin-1, and heparan sulfate proteoglycans (Jones et al. 2011). Since the HTLV-1 receptors are detected in almost all vertebrate cells, this virus can infect different types of cells in vitro (Hoshino 2012). However, HTLV-1-infected cells are associated with expression of several characteristic surface molecules including CD4, CD25, CCR4, and CADM1. HTLV-1 is predominantly transmitted by cell-to-cell contact via the virological synapse and creates new HTLV-1-infected $\mathrm{T}$ cell clones in each host (Bangham 2018). It is thought that HTLV-1 infects mature lymphocytes, macrophages, and dendritic cells in the periphery and is associated with chronic infection of this virus. Recent studies demonstrate that HTLV-1 infects hematopoietic stem cells (HSCs), and infected stem cells differentiate into diverse cell lineages (Furuta et al. 2017). However, only memory $\mathrm{CD}^{+}{ }^{+} \mathrm{T}$ cells become major viral reservoirs and express distinct surface markers, where viral factors, such as HBZ and Tax, are thought to control infected cells during HSCs differentiation.

\section{Regulatory T cells and phenotype}

HTLV-1 infection of CD4 ${ }^{+} \mathrm{T}$ cells is associated with expression of several proteins that are characteristic of Treg cells, in particular CD25, FoxP3, and CCR4. Treg cells contribute to the maintenance of immunologic self-tolerance and play an important role in chronic viral infections. In HAM/TSP patients, $\mathrm{CD} 4{ }^{+} \mathrm{CD} 25^{+} \mathrm{T}$ cells contain higher amounts of HTLV- 
1 PVL and show higher levels of HTLV-1 tax mRNA expression than in $\mathrm{CD} 4^{+} \mathrm{CD} 25^{-}$cells and produce various cytokines including INF- $\gamma$ (Yamano et al. 2004). HTLV-1-infected $\mathrm{CD} 4^{+} \mathrm{CD} 25^{+} \mathrm{T}$ cells are not functionally suppressive but rather are shown to stimulate and expand HTLV-1 Tax-specific $\mathrm{CD}^{+} \mathrm{T}$ cells (Yamano et al. 2004). Foxp3, a key transcription factor for Treg cells, is expressed in approximately $60 \%$ of ATLL cases and its function is regulated by HBZ. HBZ enhances TGF- $\beta$ signaling and promotes FoxP3 expression, and impairs the suppressive function of Treg cells in HBZ-Tg mice (Satou et al. 2011; Zhao et al. 2011). In addition, HBZ increases the number of Treg cells and converts them to Foxp $3^{-} \mathrm{T}$ cells producing IFN- $\gamma$ (Yamamoto-Taguchi et al. 2013). In HAM/TSP patients, the levels of the FoxP3 expression is decreased in $\mathrm{CD}^{+} \mathrm{CD} 25^{+} \mathrm{T}$ cells compared with ACs and healthy controls (Yamano et al. 2005; Oh et al. 2006). Furthermore, in vitro transduction of Tax reduced the FoxP3 mRNA expression and inhibited the suppressive function of the $\mathrm{CD} 4^{+} \mathrm{CD} 25^{+} \mathrm{T}$ cells isolated from healthy donors (Yamano et al. 2005).

HTLV-1 preferentially infects cells expressing CCR4 and CD4 molecules (Hieshima et al. 2008). It is well recognized that CCR4 is specifically expressed in ATLL cells, but CCR4 ${ }^{+}$ cells appear to suppressive the function of Treg cells (Bangham and Toulza 2011). HBZ-induced GATA3 expression in $\mathrm{CD}^{+} \mathrm{T}$ cells and subsequently enhanced transcriptional activity from the CCR4 promoter (Sugata et al. 2016). Upregulated CCR4 expression is associated with enhanced $\mathrm{T}$ cell migration and proliferation. In HAM/TSP patients, the frequency of IFN- $\gamma$-producing $\mathrm{CD} 4^{+} \mathrm{CD} 25^{+} \mathrm{CCR} 4^{+} \mathrm{T}$ cells is increased and correlated with disease activity and severity (Yamano et al. 2009). $\mathrm{CD}^{+} \mathrm{CCR}^{+} \mathrm{T}$ cells which express the Th1 marker CXCR3 and produce T-bet and IFN- $\gamma$ are present in the CNS (Araya et al. 2014). When stimulated by IFN- $\gamma$, astrocytes produce CXCL10 (one of the CXCR3 ligands), which recruits more $\mathrm{CXCR}^{+} \mathrm{T}$ cells, including infected cells, to the CNS (Ando et al. 2013). These cells also produce proinflammatory cytokines such as IFN- $\gamma$, which stimulates astrocytes, further creating an inflammatory positive feedback loop with subsequent tissue damage in the CNS (Yamano and Coler-Reilly 2017). Anti-CCR4 monoclonal antibody effectively reduced the proviral load and proinflammatory cytokines in PBMCs from patients with HAM/TSP (Araya et al. 2014; Yamauchi et al. 2015). Clinical trials of anti-CCR4 monoclonal antibody have been performed and showed promising results (Sato et al. 2018).

\section{Cytotoxic t lymphocytes}

The cytotoxic $\mathrm{CD}^{+} \mathrm{T}$ cells are important for the elimination of virus-infected cells. The quality of the host's CTL response to HTLV-1-infected cells play the dominant role in determining the set-point proviral load and the steady- state abundance of HTLV-1 replication (Bangham 2009). One of the most prominent features of the cellular immune response in HAM/TSP patients is that the number of HTLV-1-specific CTL is greatly elevated in PBMCs compared with ACs (Jacobson et al. 1990; Kubota et al. 2003). It is unknown why HAM/TSP patients show high proviral load in spite of their large number of CTL and whether or not the cytotoxic activity of HTLV-1-specific CTL is different between HAM/TSP patients and ACs. Recently, a functional $\mathrm{CD}^{+}$cell assay reveals no significant differences in $\mathrm{CD}^{+}$cell anti-viral efficacy between HAM/TSP patients and ACs (Asquith et al. 2005) and another functional study shows no differences in cytokine production and degranulation activity of Tax-specific CTL between the two groups (Abdelbary et al. 2011). More detailed studies are needed to investigate whether the total efficiency, but not the frequency, of HTLV-1 Tax-specific CTLs in vivo differs between HAM/TSP patients and ACs and how they contributes to the pathogenesis of HAM/TSP.

\section{Tax-specific CTL}

It has been shown that the most immunodominant HTLV-1 antigen recognized by HTLV-1-specific CTL is the Tax protein. The epitopes of $\operatorname{Tax}_{11-19}$ and $\operatorname{Tax}_{301-309}$ bind strongly to HLA-A*0201 and HLA-A*2402 respectively (Jacobson et al. 1990; Harashima et al. 2004). These virus-specific CTL produce proinflammatory cytokines and show degranulation activity (Kubota et al. 1998; Yamano et al. 2002; Abdelbary et al. 2011). Importantly, the CTL frequency is also much higher in CSF than in PBMCs and is proportional to the HTLV-1 PVL (Greten et al. 1998; Nagai et al. 2001). Tax-specific CTL are also detected in spinal cord parenchyma (Matsuura et al. 2015). Strong Tax-specific CTL response has been considered to control the viral replication and play a key role in the development of HAM/TSP. While Tax expression is generally decreased in infected cells in vivo (Hanon et al. 2000b), CTL response to Tax is chronically activated, suggesting frequent exposure to newly-synthesized Tax protein in vivo (Rende et al. 2011). A single cell analysisclarified Tax protein was expressed in intermittent but intense bursts in HTLV-1-infected cells (Billman et al. 2017; Mahgoub et al. 2018). Recently, exosomes containing Tax was identified in virus-free CSF of patients with HAM/ TSP and that in vitro, cells stimulated with Taxcontaining exosomes became targets of HTLV-1 Tax-specific CTL (Anderson et al. 2018). These mechanisms may allow activated CTL to respond to persistently HTLV-1infected cells, which may be associated with inflammatory tissue destruction. 


\section{HBZ-specific CTL}

HTLV-1 Tax-specific CTL responses have been studied extensively; however, little is known about the frequency or function of HBZ-specific CTL in HAM/TPS patients. HBZ is also an immunogenic protein recognized by HBZ-specific CTL clones and HBZ-specific CTL have been identified in ATLL or HAM/TSP patients and ACs (Suemori et al. 2009; Macnamara et al. 2010). HTLV-1-infected individuals with HLA class I alleles strongly binding the HBZ protein were shown to be related to a lower proviral load and a reduced risk of HAM/TSP (Macnamara et al. 2010; Hilburn et al. 2011). However, compared with Tax-specific CTL, HBZ-specific CTL are at a lower frequency in the peripheral blood and kills fewer HTLV-1-infected cells in vitro (Macnamara et al. 2010; Rowan et al. 2014). HBZ is continuously expressed in HTLV1-infected cells in vivo and HBZ induces the proliferation of these infected cells, thus indicating that HBZ might be a candidate antigen for cellular immunotherapy for HAM/TSP. It is necessary to identify HBZ epitopes or enhance anti-HBZ immune responses that can induce a stronger CTL response in $\mathrm{HAM} / \mathrm{TSP}$ patients.

\section{Exhaustion and inhibitory receptor in HAM/TSP}

Chronic viral infection has been reported to induce expression of inhibitory molecules that generate negative signals to downregulate the ensuing $\mathrm{T}$ cell responses. Recent translation of knowledge about inhibitory receptors such as CTLA-4 and PD-1 into cancer treatments highlights the opportunities to manipulate these pathways to treat human disease (Callahan et al. 2016). PD-1 is expressed on ATLL cells and CD8 ${ }^{+} \mathrm{T}$ cells in ATLL patients (Kozako et al. 2009; Yasuma et al. 2016b). Genomic analysis of ATLL demonstrated PD-L1 amplifications (Kataoka et al. 2018) and phase2 trial of PD-1 inhibitor therapy has been performed in patients with aggressive ATLL (Ishitsuka et al. 2018). In HAM/TSP patients, alternative expressions of various inhibitory receptors, such as PD-1, CD244, and Tim-3, have been demonstrated on $\mathrm{CD} 8^{+} \mathrm{T}$ cells (Enose-Akahata et al. 2009; Abdelbary et al. 2011; Kozako et al. 2011; Manuel et al. 2013). Some reports showed PD-1 expression is upregulated in both infected T cells and CTL (Yasuma et al. 2016b; Enose-Akahata et al. 2019) and these PD- $1^{+}$cells in $\mathrm{CD}^{+}{ }^{+}$cells showed CTL dysfunction in HAM/TSP patients (Manuel et al. 2013). T cell immunoglobulin and ITIM domain (TIGIT), which is another inhibitory molecule and expressed on activated $\mathrm{T}$ cells and Treg cells, are also highly expressed with PD-1 in HAM/ TSP patients (Yasuma et al. 2016b). Combined blockade of PD-1 and TIGIT enhanced anti-Tax T cell response in PBMCs of HAM/TSP patients. Expression of multiple distinct inhibitory receptors is associated with greater $\mathrm{T}$ ell exhaustion and rapid disease progression and co-targeting multiple inhibitory receptors show synergy and substantially more robust reversal of T cell exhaustion and control of viral load in chronic viral infection (Attanasio and Wherry 2016). A combination of checkpoint-blocking antibodies may be a potential therapeutic treatment for HAM/TSP patients and may reduce HTLV-1infected cells by recovering the function of CTL.

\section{T cell receptor repertoire analysis}

$\mathrm{T}$ cell-mediated antigen recognition depends on the interaction of the T cell receptor (TCR) with the antigen-major histocompatibility complex (MHC) molecule. The diversity of TCR repertoires is central components of adaptive immune system function and can be altered in the context of infections, malignancies or immunological disorders. Analyzing TCR repertoires may help to gain a better understanding of immune-mediated responses in neuroinflammatory diseases. In HAM/TSP patients, a previous report on the TCR analysis showed a direct demonstration of clonal expansions within both $\mathrm{CD}^{+}{ }^{+}$and $\mathrm{CD} 8^{+}$cells in HTLV-1 infections (Eiraku et al. 1998) and shared amino acid motif in the CDR3 $\beta$ in Tax-specific CTL in HLA-A*0201 HAM/TSP patients (Bourcier et al. 2001; Saito et al. 2001). With technological development based on high-throughput sequencing and bioinformatics methods, large-scale profiling of TCR repertoires have been conducted to characterize the structure of antigenrelated TCRs, cancer-infiltrating T cells, and TCRs related to autoimmunity (Rosati et al. 2017). A recent analysis showed $\mathrm{HAM}$ /TSP patients had a higher clonal $\mathrm{T}$ cell expansion in PBMCs as well as purified $\mathrm{CD} 4^{+}$and $\mathrm{CD} 8^{+}$cells compared with multiple sclerosis (Alves Sousa et al. 2019). In addition, longitudinal analysis of TCR repertoires demonstrated a correlation of the TCR clonal expansion with HTLV-1 proviral load. ATLL patients also showed monoclonal TCRs compared with ACs, and clonality data observed based on TCR repertoires were completely consistent with clonality analysis based on provirus integration sites (Rowan et al. 2016; Farmanbar et al. 2019). Recently, $\operatorname{Tax}_{301-309}$-specific CTL in HLA-A*2402 ATLL patients and ACs shared highly restricted TCR repertoires by the single-cell analysis (Ishikawa et al. 2017). It is useful to identify expanded TCR clones of antigen-specific $\mathrm{T}$ cells and/or $\mathrm{T}$ cells found in the inflammatory lesions and clarify the function of these pathogenic $\mathrm{T}$ cells. We should target more antigen-specific $\mathrm{T}$ cells or compare TCR signatures between periphery and CNS to explore pathology-related TCR signature in HAM/TSP patients.

\section{Immunopathogenesis of HAM/TSP}

The characteristic pathology of HAM/TSP consists of a chronic inflammation with diffuse degeneration throughout the central nervous system (Izumo et al. 2000). The spinal cord exhibits a loss of myelin and axons symmetrically in 
the lateral and posterior column with the inflammation of gray and white matter, which is dominant at the thoracic level (Iwasaki 1990; Yoshioka et al. 1993). These lesions are involved with perivascular and parenchymal lymphocytic infiltration with reactive astrocytosis and fibrillary gliosis (Umehara et al. 1993). Both $\mathrm{CD}^{+}{ }^{+}$and $\mathrm{CD} 8^{+}$cells are evenly distributed in active inflammatory lesions, while the predominance of $\mathrm{CD}^{+}$cells and high levels of IFN- $\gamma$ are detected in the chronic stage (Umehara et al. 1993; Aye et al. 2000). HTLV-1 mRNA and DNA are detected only in infiltrating $\mathrm{CD}^{+} \mathrm{T}$ cells in the spinal cord, but not in neural cells using in situ PCR technique (Moritoyo et al. 1996; Matsuoka et al. 1998). HTLV-1 has not been shown to actively infect neurons, oligodendrocytes, or microglia in vivo. These data strongly indicate that some of the infiltrating $\mathrm{CD} 4^{+} \mathrm{T}$ cells are infected with HTLV- 1, but the neural cells are not.

HTLV-1-specific CTL infiltrate the CNS and play a role in HAM/TSP pathogenesis (Kubota 2017). Activated HTLV-1specific CTL is markedly increased in the periphery of patients with HAM/TSP. Additionally, abundant $\mathrm{CD}^{+} \mathrm{T}$ cells infiltrate the spinal cord and express the TIA-1 molecule, which is a CTL marker (Umehara et al. 1994). A recent study visualized HTLV-1 Tax-specific CTL infiltrating the CNS using an MHC/Tax tetramer (Matsuura et al. 2015). The frequency of HTLV-1 Tax-specific CTL is more than $20 \%$ in $\mathrm{CD}^{+} \mathrm{T}$ cells infiltrating the CNS. In addition, HTLV-1 proteins are not detected in the CNS-resident cells, but they were identified in more than $60 \%$ of the infiltrating $\mathrm{CD} 4^{+} \mathrm{T}$ cells. Although neurons were generally preserved, approximately $40 \%$ of $\mathrm{CD}^{+} \mathrm{T}$ cells and some oligodendrocytes underwent apoptosis. Apoptotic oligodendrocytes were frequently in contact with $\mathrm{CD} 8^{+} \mathrm{T}$ cells, resulting in demyelination. These findings indicate that the immune responses between HTLV1-specific CTL and HTLV-1-infected $\mathrm{CD}^{+} \mathrm{T}$ cells could cause apoptosis in surrounding neural cells (bystander damage; Fig. 1). It will be necessary to elucidate the underlying mechanisms for how and why uninfected neural cells become apoptotic.

\section{Animal model}

Animal models have been widely used to study HTLV-1 viral transmission, disease pathogenesis, and treatment (Niewiesk 2016). However, there is no accurate animal model of HAM/ TSP, which has hindered the understanding of precise pathogenic mechanisms and development of effective treatments in the disease. Studies with rabbit, rat, and simian models have successfully led to the understanding of routes of transmission of the HTLV-1 virus, anti-viral immune responses, and the means of preventing its transmission (Lairmore et al. 2005). Wistar-King-Aptekman-Hokudai (WKAH) rats emerged as a model of HAM/TSP. HTLV-1-infected WKAH rats develop spastic paraparesis with degenerative thoracic spinal cord and peripheral nerve lesions after inoculation (Ishiguro et al. 1992; Kushida et al. 1993). However, lesions in humans showed a marked $\mathrm{T}$ cell infiltration of affected regions, while lesions in the rats did not. In addition, the HTLV-1 provirus has been identified in microglia/macrophages associated with lesions in rats, in contrast with humans (Kasai et al. 1999). Therefore, the pathogenesis of the rat model is considered to be different from that of human HAM/TSP. Mouse models have traditionally been cost-effective and easy to develop and maintain. Hence, mice have been manipulated to establish HTLV-1 infection through the generation of transgenic and humanized mice models. One such model is the Tax-transgenic mouse, which restricts Tax expression to developing thymocytes, demonstrating characteristic ATLL-like phenotypes (Hasegawa et al. 2006). Another common feature of Tax-Tg mice is the development of chronic arthritis at 2-3 months (Panfil et al. 2013) and a small portion (8/297) of Tax-Tg mice developed HAM/TSP-like disease with symmetrical paraparesis of the hind limbs though it was caused by the invasion of histiocytic sarcoma cells into the lumbar spinal cord (Ohsugi et al. 2013). Another model, the HBZtransgenic mouse, expressed HBZ under the control of a CD4 promoter leads to inflammation in skin and lung as well as T cell lymphoma (Satou et al. 2011). However, currently, there is no report that HBZ-Tg mice develop inflammatory neurologic diseases and it remains unknown how tissue specificity of HTLV-1 associated inflammatory diseases are determined. A recent development is the use of humanized mice which, upon transfer of $\mathrm{CD} 34^{+}$human umbilical cord stem cells, generate human lymphocytes (Niewiesk 2016). Inoculation of immunodeficient mice with ATLL cells or HTLV-1 transformed cell lines provide an opportunity to investigate disease development and evaluate treatment for ATLL. Recently, humanized mice model using Balb/c$\operatorname{Rag} 1^{-/-} \gamma \mathrm{c}^{-/-}$and bone marrow-liver-thymic mouse showed establishment of peripheral infection that led to lymphocytic infiltration with concomitant Tax expression and resulting myelin disruption within the CNS of infected mice (Ginwala et al. 2017). In addition, upregulation in the expression of several immune checkpoint mediators such as PD-1, TIGIT, and Tim- 3 was observed on $\mathrm{CD} 8^{+} \mathrm{T}$ cells in various organs including the CNS of infected hu-mice. This humanized mouse model could be a suitable model to evaluate the imunopathogenesis and develop a novel treatment for HAM/ TSP.

\section{Treatment}

In HAM/TAP, most therapeutic trials have aimed to inhibit or regulate the immune response, or to reduce the HTLV-1 proviral load in an attempt to decrease the risk or alter the course of the disease. Corticosteroids are most widely used to decrease the inflammation in the CNS, particularly in the early 


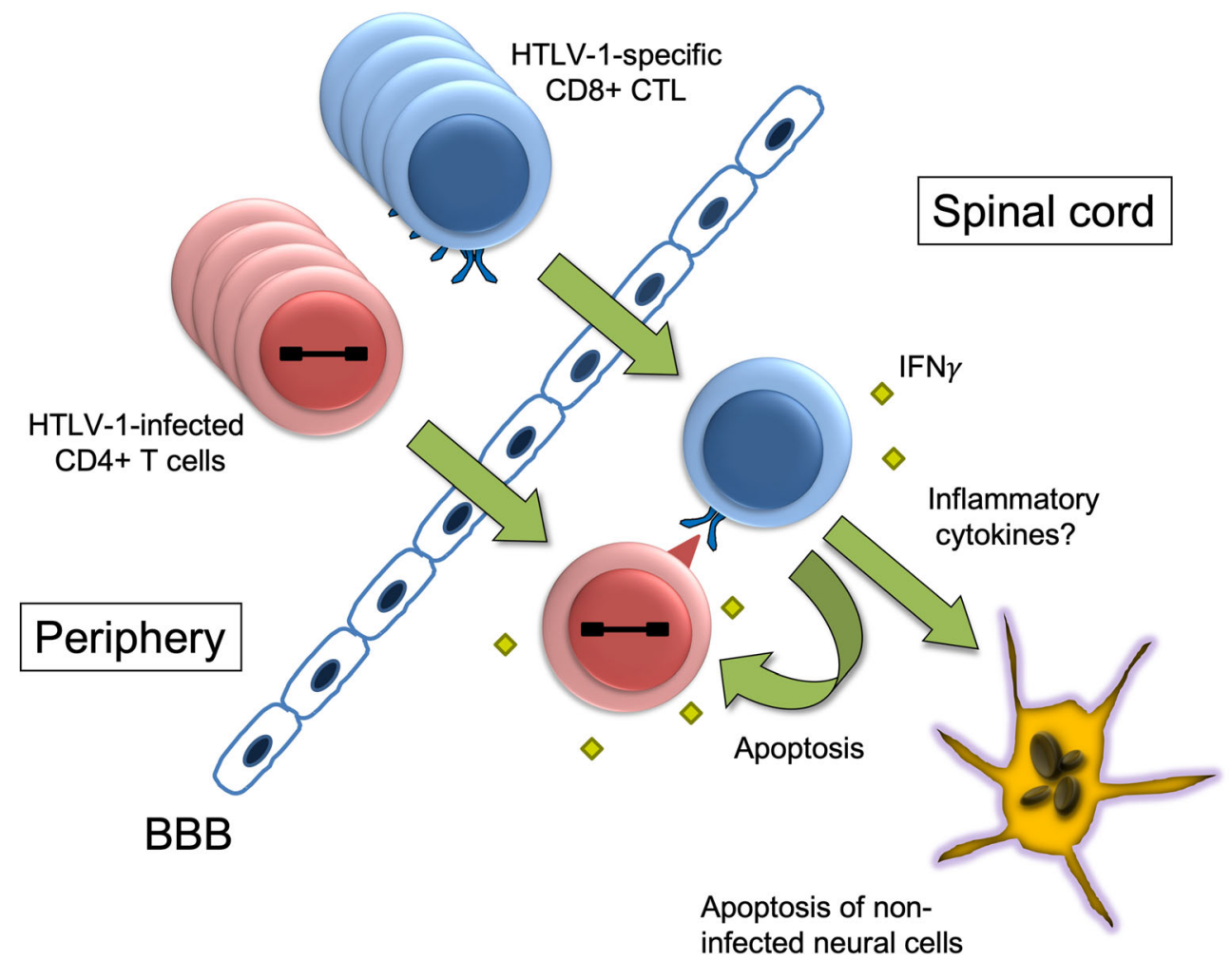

Fig. 1 Proposed model of the immunopathology in human Tlymphotropic virus type 1 (HTLV-1)-associated myelopathy/tropical spastic paraparesis: bystander neural damage. HTLV-1-infected CD4 ${ }^{+}$ $\mathrm{T}$ cells proliferate in the periphery and circulate in HTLV-1-infected individuals. The infected cells invade the central nervous system across the blood-brain barrier and express viral antigens. HTLV-1-specific cytotoxic T lymphocytes (CTL) are activated and expanded on stimulation by the HTLV-1 antigens and accumulate in the spinal cord. The CTL

stage. Motor disability in some patients could be improved with steroids (Nakagawa et al. 1996; Croda et al. 2008), but improvement is typically not maintained and the drug is discontinued due to various side effects. IFN- $\alpha$ is a medication in which efficacy was demonstrated in randomized placebo-controlled trials (Izumo et al. 1996; Arimura et al. 2007); however, the therapeutic benefit is insufficient. Reverse transcriptase inhibitors, which are used to treat HIV-1 infection, were not effective against HTLV-1 in clinical trials (Taylor et al. 2006; Macchi et al. 2011). Recently, a humanized anti-CCR4 monoclonal antibody, mogamulizumab, effectively reduced both the PVL and inflammatory activity in cells obtained from patients with HAM/TSP (Yamauchi et al. 2015). Phase 1/2a clinical trials revealed the safety and short-term effectiveness of mogamulizumab in patients with HAM/TSP (Sato et al. 2018). Hu-Mik $\beta 1$, which is a humanized monoclonal antibody against the $\beta$ subunit shared by the IL- 2 and IL- 15 receptors (IL-2/IL-15R $\beta$; CD122), has been reported to inhibit abnormal $\mathrm{T}$ cell proliferation and HTLV-1-specific cellular immune responses by blocking IL-15 action in HAM/TSP patients (Azimi et al. 1999; Enose-Akahata et al. 2008). The recognize viral antigens presented by human leukocyte antigen class I molecules on the infiltrating HTLV-1-infected $\mathrm{CD}^{+} \mathrm{T}$ cells, leading to the secretion of proinflammatory cytokines, such as interferon- $\gamma$ and tumor necrosis factor- $\alpha$. HTLV-1-specific inflammation mediated by the interaction of HTLV-1-infected CD4 ${ }^{+} \mathrm{T}$ cells with HTLV-1-specific CTL causes apoptosis in adjacent neural cells (bystander damage) in the $\mathrm{CNS}$, resulting in tissue destruction and degeneration. BBB, blood-brain barrier

treatment with $\mathrm{Hu}-\mathrm{Mik} \beta 1$ showed the inhibition of aberrant $\mathrm{CD}^{+} \mathrm{T}$ cell function in HAM/TSP patients although no clinical efficacy was observed (Enose-Akahata et al. 2019). Raltegravir, which is an integrase inhibitor used for the treatment of HIV-1, was reported to reduce cell-free and cell-tocell transmission of HTLV-1 in vitro (Seegulam and Ratner 2011). Since high PVL is known to be the main risk factor for developing HAM/TSP in infected subjects, PVL reduction is a reasonable therapeutic goal. The trial of raltegravir is currently underway.

\section{Conclusion}

HTLV-1 preferentially infects $\mathrm{CD} 4^{+} \mathrm{T}$ cells and establish infected $\mathrm{T}$ cell clones in the host, regulating the balance between proviral latency and reactivation. Clonal expanded $\mathrm{T}$ cells infected with HTLV-1 dysregulate T cell function and differentiation and subsequently induce HTLV-1-specific T cell responses. These cell-mediated immune responses and released proinflammatory cytokines could cause neural damage, which is thought to play a central role in the development of 
HAM/TSP. Recent advances in research provide a better understanding of mechanisms associated with HTLV-1-infected cells and cellular immune responses in HAM/TSP. Further research will be required to develop strategies to eliminate HTLV-1-infected cells or enhance cellular immunity for the development of effective treatments in patients with HAM/ TSP.

Funding information Satoshi Nozuma was supported by the Japan Society for the Promotion of Science - JSPS-NIH Research Fellowship Program. This work was supported by the Intramural Research Program of the National Institute of Neurological Disorders and Stroke, National Institutes of Health.

Open Access This article is licensed under a Creative Commons Attribution 4.0 International License, which permits use, sharing, adaptation, distribution and reproduction in any medium or format, as long as you give appropriate credit to the original author(s) and the source, provide a link to the Creative Commons licence, and indicate if changes were made. The images or other third party material in this article are included in the article's Creative Commons licence, unless indicated otherwise in a credit line to the material. If material is not included in the article's Creative Commons licence and your intended use is not permitted by statutory regulation or exceeds the permitted use, you will need to obtain permission directly from the copyright holder. To view a copy of this licence, visit http://creativecommons.org/licenses/by/4.0/.

\section{References}

Abdelbary NH, Abdullah HM, Matsuzaki T, Hayashi D, Tanaka Y, Takashima H, Izumo S, Kubota R (2011) Reduced Tim-3 expression on human T-lymphotropic virus type I (HTLV-I) Tax-specific cytotoxic T lymphocytes in HTLV-I infection. J Infect Dis 203(7): 948-959. https://doi.org/10.1093/infdis/jiq153

Alvarez C, Gotuzzo E, Vandamme AM, Verdonck K (2016) Family aggregation of human T-Lymphotropic virus 1-associated diseases: a systematic review. Front Microbiol 7:1674. https://doi.org/10. 3389/fmicb.2016.01674

Alves Sousa AP, Johnson KR, Ohayon J, Zhu J, Muraro PA, Jacobson S (2019) Comprehensive analysis of TCR-beta repertoire in patients with neurological immune-mediated disorders. Sci Rep 9(1):344. https://doi.org/10.1038/s41598-018-36274-7

Anderson MR, Pleet ML, Enose-Akahata Y, Erickson J, Monaco MC, Akpamagbo Y, Velluci A, Tanaka Y, Azodi S, Lepene B, Jones J, Kashanchi F, Jacobson S (2018) Viral antigens detectable in CSF exosomes from patients with retrovirus associated neurologic disease: functional role of exosomes. Clin Transl Med 7(1):24. https:// doi.org/10.1186/s40169-018-0204-7

Ando H, Sato T, Tomaru U, Yoshida M, Utsunomiya A, Yamauchi J, Araya N, Yagishita N, Coler-Reilly A, Shimizu Y, Yudoh K, Hasegawa Y, Nishioka K, Nakajima T, Jacobson S, Yamano Y (2013) Positive feedback loop via astrocytes causes chronic inflammation in virus-associated myelopathy. Brain 136(Pt 9):2876-2887. https://doi.org/10.1093/brain/awt183

Araya N, Sato T, Ando H, Tomaru U, Yoshida M, Coler-Reilly A, Yagishita N, Yamauchi J, Hasegawa A, Kannagi M, Hasegawa Y, Takahashi K, Kunitomo Y, Tanaka Y, Nakajima T, Nishioka K, Utsunomiya A, Jacobson S, Yamano Y (2014) HTLV-1 induces a Th1-like state in CD4+CCR4+ T cells. J Clin Invest 124(8):34313442. https://doi.org/10.1172/JCI75250
Arimura K, Nakagawa M, Izumo S, Usuku K, Itoyama Y, Kira J, Osame M (2007) Safety and efficacy of interferon-alpha in 167 patients with human T-cell lymphotropic virus type 1-associated myelopathy. J Neuro-Oncol 13(4):364-372. https://doi.org/10.1080/ 13550280701397627

Arnold J, Zimmerman B, Li M, Lairmore MD, Green PL (2008) Human T-cell leukemia virus type-1 antisense-encoded gene, Hbz, promotes T-lymphocyte proliferation. Blood 112(9):3788-3797. https://doi. org/10.1182/blood-2008-04-154286

Asquith B, Mosley AJ, Barfield A, Marshall SE, Heaps A, Goon P et al (2005) A functional CD8+ cell assay reveals individual variation in CD8+ cell antiviral efficacy and explains differences in human Tlymphotropic virus type 1 proviral load. J Gen Virol 86(Pt 5):15151523. https://doi.org/10.1099/vir.0.80766-0

Attanasio J, Wherry EJ (2016) Costimulatory and coinhibitory receptor pathways in infectious disease. Immunity 44(5):1052-1068. https:// doi.org/10.1016/j.immuni.2016.04.022

Aye MM, Matsuoka E, Moritoyo T, Umehara F, Suehara M, Hokezu Y, Yamanaka H, Isashiki Y, Osame M, Izumo S (2000) Histopathological analysis of four autopsy cases of HTLV-Iassociated myelopathy/tropical spastic paraparesis: inflammatory changes occur simultaneously in the entire central nervous system. Acta Neuropathol 100(3):245-252

Azimi N, Jacobson S, Leist T, Waldmann TA (1999) Involvement of IL15 in the pathogenesis of human T lymphotropic virus type Iassociated myelopathy/tropical spastic paraparesis: implications for therapy with a monoclonal antibody directed to the IL-2/15R beta receptor. J Immunol 163(7):4064-4072

Bangham CR (2009) CTL quality and the control of human retroviral infections. Eur J Immunol 39(7):1700-1712. https://doi.org/10. 1002/eji.200939451

Bangham CR, Toulza F (2011) Adult T cell leukemia/lymphoma: FoxP3(+) cells and the cell-mediated immune response to HTLV1. Adv Cancer Res 111:163-182. https://doi.org/10.1016/B978-012-385524-4.00004-0

Bangham CRM (2018) Human T cell leukemia virus type 1: persistence and pathogenesis. Annu Rev Immunol 36:43-71. https://doi.org/10. 1146/annurev-immunol-042617-053222

Baratella M, Forlani G, Raval GU, Tedeschi A, Gout O, Gessain A, Tosi G, Accolla RS (2017) Cytoplasmic localization of HTLV-1 HBZ protein: a biomarker of HTLV-1-associated myelopathy/tropical spastic paraparesis (HAM/TSP). PLoS Negl Trop Dis 11(1): e0005285. https://doi.org/10.1371/journal.pntd.0005285

Billman MR, Rueda D, Bangham CRM (2017) Single-cell heterogeneity and cell-cycle-related viral gene bursts in the human leukaemia virus HTLV-1. Wellcome Open Res 2:87. https://doi.org/10.12688/ wellcomeopenres. 12469.2

Bourcier KD, Lim DG, Ding YH, Smith KJ, Wucherpfennig K, Hafler DA (2001) Conserved CDR3 regions in T-cell receptor (TCR) CD8(+) T cells that recognize the Tax11-19/HLA-A*0201 complex in a subject infected with human T-cell leukemia virus type 1: relationship of T-cell fine specificity and major histocompatibility complex/peptide/TCR crystal structure. J Virol 75(20):9836-9843. https://doi.org/10.1128/JVI.75.20.9836-9843.2001

Callahan MK, Postow MA, Wolchok JD (2016) Targeting T cell coreceptors for cancer therapy. Immunity 44(5):1069-1078. https:// doi.org/10.1016/j.immuni.2016.04.023

Coler-Reilly AL, Yagishita N, Suzuki H, Sato T, Araya N, Inoue E et al (2016) Nation-wide epidemiological study of Japanese patients with rare viral myelopathy using novel registration system (HAM-net). Orphanet J Rare Dis 11(1):69. https://doi.org/10.1186/s13023-0160451-x

Cook LB, Rowan AG, Melamed A, Taylor GP, Bangham CR (2012) HTLV-1-infected T cells contain a single integrated provirus in natural infection. Blood 120(17):3488-3490. https://doi.org/10.1182/ blood-2012-07-445593 
Croda MG, de Oliveira AC, Vergara MP, Bonasser F, Smid J, Duarte AJ et al (2008) Corticosteroid therapy in TSP/HAM patients: the results from a 10 years open cohort. J Neurol Sci 269(1-2):133-137. https://doi.org/10.1016/j.jns.2008.01.004

Einsiedel LJ, Pham H, Woodman RJ, Pepperill C, Taylor KA (2016) The prevalence and clinical associations of HTLV-1 infection in a remote indigenous community. Med J Aust 205(7):305-309

Eiraku N, Hingorani R, Ijichi S, Machigashira K, Gregersen PK, Monteiro J et al (1998) Clonal expansion within CD4+ and CD8+ $\mathrm{T}$ cell subsets in human $\mathrm{T}$ lymphotropic virus type I-infected individuals. J Immunol 161(12):6674-6680

Enose-Akahata Y, Abrams A, Massoud R, Bialuk I, Johnson KR, Green PL, Maloney EM, Jacobson S (2013) Humoral immune response to HTLV-1 basic leucine zipper factor (HBZ) in HTLV-1-infected individuals. Retrovirology 10:19. https://doi.org/10.1186/1742-469010-19

Enose-Akahata Y, Matsuura E, Oh U, Jacobson S (2009) High expression of CD244 and SAP regulated CD8 T cell responses of patients with HTLV-I associated neurologic disease. PLoS Pathog 5(12): e1000682. https://doi.org/10.1371/journal.ppat.1000682

Enose-Akahata Y, Oh U, Grant C, Jacobson S (2008) Retrovirally induced CTL degranulation mediated by IL-15 expression and infection of mononuclear phagocytes in patients with HTLV-I-associated neurologic disease. Blood 112(6):2400-2410. https://doi.org/10. 1182/blood-2008-02-138529

Enose-Akahata Y, Oh U, Ohayon J, Billioux BJ, Massoud R, Bryant BR, Vellucci A, Ngouth N, Cortese I, Waldmann TA, Jacobson S (2019) Clinical trial of a humanized anti-IL-2/IL-15 receptor beta chain in HAM/TSP. Ann Clin Transl Neurol 6(8):1383-1394. https://doi. org/10.1002/acn3.50820

Enose-Akahata Y, Vellucci A, Jacobson S (2017) Role of HTLV-1 Tax and HBZ in the pathogenesis of HAM/TSP. Front Microbiol 8: 2563. https://doi.org/10.3389/fmicb.2017.02563

Farmanbar A, Kneller R, Firouzi S (2019) RNA sequencing identifies clonal structure of T-cell repertoires in patients with adult T-cell leukemia/lymphoma. NPJ Genom Med 4:10. https://doi.org/10. 1038/s41525-019-0084-9

Forlani G, Baratella M, Tedeschi A, Pique C, Jacobson S, Accolla RS (2019) HTLV-1 HBZ protein resides exclusively in the cytoplasm of infected cells in asymptomatic carriers and HAM/TSP patients. Front Microbiol 10:819. https://doi.org/10.3389/fmicb.2019.00819

Furukawa Y, Yamashita M, Usuku K, Izumo S, Nakagawa M, Osame M (2000) Phylogenetic subgroups of human T cell lymphotropic virus (HTLV) type I in the Tax gene and their association with different risks for HTLV-I-associated myelopathy/tropical spastic paraparesis. J Infect Dis 182(5):1343-1349. https://doi.org/10. 1086/315897

Furuta R, Yasunaga JI, Miura M, Sugata K, Saito A, Akari H, Ueno T, Takenouchi N, Fujisawa JI, Koh KR, Higuchi Y, Mahgoub M, Shimizu M, Matsuda F, Melamed A, Bangham CR, Matsuoka M (2017) Human T-cell leukemia virus type 1 infects multiple lineage hematopoietic cells in vivo. PLoS Pathog 13(11):e1006722. https:// doi.org/10.1371/journal.ppat.1006722

Gaudray G, Gachon F, Basbous J, Biard-Piechaczyk M, Devaux C, Mesnard JM (2002) The complementary strand of the human Tcell leukemia virus type 1 RNA genome encodes a bZIP transcription factor that down-regulates viral transcription. J Virol 76(24): 12813-12822

Gessain A, Barin F, Vernant JC, Gout O, Maurs L, Calender A, de Thé G (1985) Antibodies to human T-lymphotropic virus type-I in patients with tropical spastic paraparesis. Lancet 2(8452):407-410

Gessain A, Cassar O (2012) Epidemiological aspects and world distribution of HTLV-1 infection. Front Microbiol 3:388. https://doi.org/10. 3389/fmicb.2012.00388

Gessain A, Mahieux R (2012) Tropical spastic paraparesis and HTLV-1 associated myelopathy: clinical, epidemiological, virological and therapeutic aspects. Rev Neurol (Paris) 168(3):257-269. https:// doi.org/10.1016/j.neurol.2011.12.006

Ginwala R, Caruso B, Khan ZK, Pattekar A, Chew GM, Corley MJ, Loonawat R, Jacobson S, Sreedhar S, Ndhlovu LC, Jain P (2017) HTLV-1 infection and Neuropathogenesis in the context of Rag1(-/gammac(-/-) (RAG1-Hu) and BLT mice. J NeuroImmune Pharmacol 12(3):504-520. https://doi.org/10.1007/s11481-0179740-y

Greten TF, Slansky JE, Kubota R, Soldan SS, Jaffee EM, Leist TP, Pardoll DM, Jacobson S, Schneck JP (1998) Direct visualization of antigen-specific T cells: HTLV-1 Tax11-19-specific CD8(+) T cells are activated in peripheral blood and accumulate in cerebrospinal fluid from HAM/TSP patients. Proc Natl Acad Sci U S A 95(13): 7568-7573

Hanon E, Asquith RE, Taylor GP, Tanaka Y, Weber JN, Bangham CR (2000a) High frequency of viral protein expression in human T cell lymphotropic virus type 1-infected peripheral blood mononuclear cells. AIDS Res Hum Retrovir 16(16):1711-1715. https://doi.org/ 10.1089/08892220050193191

Hanon E, Hall S, Taylor GP, Saito M, Davis R, Tanaka Y, Usuku K, Osame M, Weber JN, Bangham CRM (2000b) Abundant Tax protein expression in CD4+ $\mathrm{T}$ cells infected with human T-cell lymphotropic virus type I (HTLV-I) is prevented by cytotoxic T lymphocytes. Blood 95(4):1386-1392

Harashima N, Kurihara K, Utsunomiya A, Tanosaki R, Hanabuchi S, Masuda M, Ohashi T, Fukui F, Hasegawa A, Masuda T, Takaue Y, Okamura J, Kannagi M (2004) Graft-versus-Tax response in adult T-cell leukemia patients after hematopoietic stem cell transplantation. Cancer Res 64(1):391-399. https://doi.org/10.1158/ 0008-5472.can-03-1452

Hasegawa H, Sawa H, Lewis MJ, Orba Y, Sheehy N, Yamamoto Y, Ichinohe T, Tsunetsugu-Yokota Y, Katano H, Takahashi H, Matsuda J, Sata T, Kurata T, Nagashima K, Hall WW (2006) Thymus-derived leukemia-lymphoma in mice transgenic for the Tax gene of human T-lymphotropic virus type I. Nat Med 12(4): 466-472. https://doi.org/10.1038/nm1389

Hieshima K, Nagakubo D, Nakayama T, Shirakawa AK, Jin Z, Yoshie O (2008) Tax-inducible production of CC chemokine ligand 22 by human $\mathrm{T}$ cell leukemia virus type 1 (HTLV-1)-infected T cells promotes preferential transmission of HTLV-1 to CCR4-expressing CD4+ T cells. J Immunol 180(2):931-939

Hilburn S, Rowan A, Demontis MA, MacNamara A, Asquith B, Bangham CR, Taylor GP (2011) In vivo expression of human Tlymphotropic virus type 1 basic leucine-zipper protein generates specific CD8+ and CD4+ T-lymphocyte responses that correlate with clinical outcome. J Infect Dis 203(4):529-536. https://doi.org/ 10.1093/infdis/jiq078

Hivin P, Frederic M, Arpin-Andre C, Basbous J, Gay B, Thebault S et al (2005) Nuclear localization of HTLV-I bZIP factor (HBZ) is mediated by three distinct motifs. J Cell Sci 118(Pt 7):1355-1362. https:// doi.org/10.1242/jcs.01727

Hoshino H (2012) Cellular factors involved in HTLV-1 entry and pathogenicit. Front Microbiol 3:222. https://doi.org/10.3389/fmicb. 2012.00222

Ishiguro N, Abe M, Seto K, Sakurai H, Ikeda H, Wakisaka A, Togashi T, Tateno M, Yoshiki T (1992) A rat model of human T lymphocyte virus type I (HTLV-I) infection. 1. Humoral antibody response, provirus integration, and HTLV-I-associated myelopathy/tropical spastic paraparesis-like myelopathy in seronegative HTLV-I carrier rats. J Exp Med 176(4):981-989. https://doi.org/10.1084/jem.176.4. 981

Ishikawa C, Senba M, Hashimoto T, Imaizumi A, Mori N (2017) Expression and significance of Pim-3 kinase in adult T-cell leukemia. Eur J Haematol 99(6):495-504. https://doi.org/10.1111/ejh. 12940 
Ishitsuka K, Utsunomiya A, Ishida T (2018) PD-1 inhibitor therapy in adult T-cell leukemia-lymphoma. N Engl J Med 379(7):695-697. https://doi.org/10.1056/NEJMc1807852

Iwasaki Y (1990) Pathology of chronic myelopathy associated with HTLV-I infection (HAM/TSP). J Neurol Sci 96(1):103-123

Izumo S, Goto I, Itoyama Y, Okajima T, Watanabe S, Kuroda Y, Araki S, Mori M, Nagataki M, Matsukura S, Akamine T, Nakagawa M, Yamamoto I, Osame M (1996) Interferon-alpha is effective in HTLV-I-associated myelopathy: a multicenter, randomized, double-blind, controlled trial. Neurology 46(4):1016-1021

Izumo S, Umehara F, Osame M (2000) HTLV-I-associated myelopathy. Neuropathology 20(Suppl):S65-S68

Jacobson S, Shida H, McFarlin DE, Fauci AS, Koenig S (1990) Circulating CD8+ cytotoxic T lymphocytes specific for HTLV-I $\mathrm{pX}$ in patients with HTLV-I associated neurological disease. Nature 348(6298):245-248. https://doi.org/10.1038/348245a0

Jones KS, Lambert S, Bouttier M, Benit L, Ruscetti FW, Hermine O et al (2011) Molecular aspects of HTLV-1 entry: functional domains of the HTLV-1 surface subunit (SU) and their relationships to the entry receptors. Viruses 3(6):794-810. https://doi.org/10.3390/v3060794

Kasai T, Ikeda H, Tomaru U, Yamashita I, Ohya O, Morita K et al (1999) A rat model of human T lymphocyte virus type I (HTLV-I) infection: in situ detection of HTLV-I provirus DNA in microglia/ macrophages in affected spinal cords of rats with HTLV-1induced chronic progressive myeloneuropathy. Acta Neuropathologica 97(2):107-112. https://doi.org/10.1007/ s004010050962

Kataoka K, Iwanaga M, Yasunaga JI, Nagata Y, Kitanaka A, Kameda T, Yoshimitsu M, Shiraishi Y, Sato-Otsubo A, Sanada M, Chiba K, Tanaka H, Ochi Y, Aoki K, Suzuki H, Shiozawa Y, Yoshizato T, Sato Y, Yoshida K, Nosaka K, Hishizawa M, Itonaga H, Imaizumi Y, Munakata W, Shide K, Kubuki Y, Hidaka T, Nakamaki T, Ishiyama K, Miyawaki S, Ishii R, Nureki O, Tobinai K, Miyazaki Y, Takaori-Kondo A, Shibata T, Miyano S, Ishitsuka K, Utsunomiya A, Shimoda K, Matsuoka M, Watanabe T, Ogawa S (2018) Prognostic relevance of integrated genetic profiling in adult T-cell leukemia/lymphoma. Blood 131(2):215-225. https://doi.org/ 10.1182/blood-2017-01-761874

Kawatsuki A, Yasunaga JI, Mitobe Y, Green PL, Matsuoka M (2016) HTLV-1 bZIP factor protein targets the Rb/E2F-1 pathway to promote proliferation and apoptosis of primary CD4(+) T cells. Oncogene 35(34):4509-4517. https://doi.org/10.1038/onc.2015. 510

Kinosada H, Yasunaga JI, Shimura K, Miyazato P, Onishi C, Iyoda T, Inaba K, Matsuoka M (2017) HTLV-1 bZIP factor enhances T-cell proliferation by impeding the suppressive signaling of co-inhibitory receptors. PLoS Pathog 13(1):e1006120. https://doi.org/10.1371/ journal.ppat. 1006120

Komurian F, Pelloquin F, de The G (1991) In vivo genomic variability of human T-cell leukemia virus type I depends more upon geography than upon pathologies. J Virol 65(7):3770-3778

Kozako T, Yoshimitsu M, Akimoto M, White Y, Matsushita K, Soeda S, Shimeno H, Kubota R, Izumo S, Arima N (2011) Programmed death-1 (PD-1)/PD-1 ligand pathway-mediated immune responses against human T-lymphotropic virus type 1 (HTLV-1) in HTLV-1associated myelopathy/tropical spastic paraparesis and carriers with autoimmune disorders. Hum Immunol 72(11):1001-1006. https:// doi.org/10.1016/j.humimm.2011.07.308

Kozako T, Yoshimitsu M, Fujiwara H, Masamoto I, Horai S, White Y, Akimoto M, Suzuki S, Matsushita K, Uozumi K, Tei C, Arima N (2009) PD-1/PD-L1 expression in human T-cell leukemia virus type 1 carriers and adult T-cell leukemia/lymphoma patients. Leukemia 23(2):375-382. https://doi.org/10.1038/leu.2008.272

Kubota R (2017) Pathogenesis of human T-lymphotropic virus type 1associated myelopathy/tropical spastic paraparesis. Clin Exp Neuroimmunol 8(2):117-128. https://doi.org/10.1111/cen3.12395
Kubota R, Furukawa Y, Izumo S, Usuku K, Osame M (2003) Degenerate specificity of HTLV-1-specific CD8+ T cells during viral replication in patients with HTLV-1-associated myelopathy (HAM/TSP). Blood 101(8):3074-3081. https://doi.org/10.1182/blood-2002-082477

Kubota R, Kawanishi T, Matsubara H, Manns A, Jacobson S (1998) Demonstration of human T lymphotropic virus type I (HTLV-I) Tax-specific CD8+ lymphocytes directly in peripheral blood of HTLV-I-associated myelopathy/tropical spastic paraparesis patients by intracellular cytokine detection. J Immunol 161(1):482-488

Kushida S, Matsumura M, Tanaka H, Ami Y, Hori M, Kobayashi M, Uchida K, Yagami KI, Kameyama T, Yoshizawa T, Mizusawa H, Iwasaki Y, Miwa M (1993) HTLV-1-associated myelopathy/ tropical spastic paraparesis-like rats by intravenous injection of HTLV-1-producing rabbit or human T-cell line into adult WKA rats. Jpn J Cancer Res 84(8):831-833. https://doi.org/10.1111/j.13497006.1993.tb02052.x

Lairmore MD, Silverman L, Ratner L (2005) Animal models for human T-lymphotropic virus type 1 (HTLV-1) infection and transformation. Oncogene 24(39):6005-6015. https://doi.org/10.1038/sj.onc. 1208974

Macchi B, Balestrieri E, Ascolani A, Hilburn S, Martin F, Mastino A, Taylor GP (2011) Susceptibility of primary HTLV-1 isolates from patients with HTLV-1-associated myelopathy to reverse transcriptase inhibitors. Viruses 3(5):469-483. https://doi.org/10.3390/ v3050469

Macnamara A, Rowan A, Hilburn S, Kadolsky U, Fujiwara H, Suemori K et al (2010) HLA class I binding of HBZ determines outcome in HTLV-1 infection. PLoS Pathog 6(9):e1001117. https://doi.org/10. 1371/journal.ppat. 1001117

Mahgoub M, Yasunaga JI, Iwami S, Nakaoka S, Koizumi Y, Shimura K, Matsuoka M (2018) Sporadic on/off switching of HTLV-1 Tax expression is crucial to maintain the whole population of virusinduced leukemic cells. Proc Natl Acad Sci U S A 115(6):E1269E1278. https://doi.org/10.1073/pnas.1715724115

Mahieux R, de The G, Gessain A (1995) The Tax mutation at nucleotide 7959 of human T-cell leukemia virus type 1 (HTLV-1) is not associated with tropical spastic paraparesis/HTLV-1-associated myelopathy but is linked to the cosmopolitan molecular genotype. J Virol 69(9):5925-5927

Manuel SL, Sehgal M, Connolly J, Makedonas G, Khan ZK, Gardner J, Betts MR, Jain P (2013) Lack of recall response to Tax in ATL and HAM/TSP patients but not in asymptomatic carriers of human Tcell leukemia virus type 1. J Clin Immunol 33(7):1223-1239. https://doi.org/10.1007/s10875-013-9918-x

Matsuoka E, Takenouchi N, Hashimoto K, Kashio N, Moritoyo T, Higuchi I, Isashiki Y, Sato E, Osame M, Izumo S (1998) Perivascular T cells are infected with HTLV-I in the spinal cord lesions with HTLV-I-associated myelopathy/tropical spastic paraparesis: double staining of immunohistochemistry and polymerase chain reaction in situ hybridization. Acta Neuropathol 96(4): 340-346

Matsuoka M, Jeang KT (2011) Human T-cell leukemia virus type 1 (HTLV-1) and leukemic transformation: viral infectivity, Tax, HBZ and therapy. Oncogene 30(12):1379-1389. https://doi.org/ 10.1038/onc.2010.537

Matsuura E, Kubota R, Tanaka Y, Takashima H, Izumo S (2015) Visualization of HTLV-1-specific cytotoxic T lymphocytes in the spinal cords of patients with HTLV-1-associated myelopathy/ tropical spastic paraparesis. J Neuropathol Exp Neurol 74(1):2-14. https://doi.org/10.1097/NEN.0000000000000141

Moritoyo T, Reinhart TA, Moritoyo H, Sato E, Izumo S, Osame M et al (1996) Human T-lymphotropic virus type I-associated myelopathy and Tax gene expression in CD4+ T lymphocytes. Ann Neurol 40(1):84-90. https://doi.org/10.1002/ana.410400114 
Nagai M, Usuku K, Matsumoto W, Kodama D, Takenouchi N, Moritoyo T et al (1998) Analysis of HTLV-I proviral load in $202 \mathrm{HAM}$ /TSP patients and 243 asymptomatic HTLV-I carriers: high proviral load strongly predisposes to HAM/TSP. J Neuro-Oncol 4(6):586-593

Nagai M, Yamano Y, Brennan MB, Mora CA, Jacobson S (2001) Increased HTLV-I proviral load and preferential expansion of HTLV-I Tax-specific CD8+ T cells in cerebrospinal fluid from patients with HAM/TSP. Ann Neurol 50(6):807-812

Naito T, Yasunaga JI, Mitobe Y, Shirai K, Sejima H, Ushirogawa H, Tanaka Y, Nakamura T, Hanada K, Fujii M, Matsuoka M, Saito M (2018) Distinct gene expression signatures induced by viral transactivators of different HTLV-1 subgroups that confer a different risk of HAM/TSP. Retrovirology 15(1):72. https://doi.org/10. 1186/s12977-018-0454-x

Nakagawa M, Nakahara K, Maruyama Y, Kawabata M, Higuchi I, Kubota $\mathrm{H}$ et al (1996) Therapeutic trials in 200 patients with HTLV-I-associated myelopathy/ tropical spastic paraparesis. J Neuro-Oncol 2(5):345-355

Niewiesk S (2016) Animals models of human T cell leukemia virus type I leukemogenesis. ILAR J 57(1):3-11. https://doi.org/10.1093/ilar/ ilv045

Nozuma S, Matsuura E, Kodama D, Tashiro Y, Matsuzaki T, Kubota R, Izumo S, Takashima $\mathrm{H}$ (2017) Effects of host restriction factors and the HTLV-1 subtype on susceptibility to HTLV-1-associated myelopathy/tropical spastic paraparesis. Retrovirology 14(1):26. https://doi.org/10.1186/s12977-017-0350-9

Nozuma S, Matsuura E, Matsuzaki T, Watanabe O, Kubota R, Izumo S, Takashima H (2014) Familial clusters of HTLV-1-associated myelopathy/tropical spastic paraparesis. PLoS One 9(5):e86144. https://doi.org/10.1371/journal.pone.0086144

Oh U, Grant C, Griffith C, Fugo K, Takenouchi N, Jacobson S (2006) Reduced Foxp3 protein expression is associated with inflammatory disease during human $t$ lymphotropic virus type 1 infection. J Infect Dis 193(11):1557-1566. https://doi.org/10.1086/503874

Ohsugi T, Wakamiya M, Morikawa S, Matsuura K, Kumar JM, Kumasaka T, Yamaguchi K (2013) Invasion of histiocytic sarcoma into the spinal cord of HTLV-1 Tax transgenic mice with HTLV-1associated myelopathy/tropical spastic paraparesis-like disease. Oncol Res 20(9):403-410. https://doi.org/10.3727/ $096504013 X 13657689383058$

Olindo S, Cabre P, Lezin A, Merle H, Saint-Vil M, Signate A et al (2006) Natural history of human T-lymphotropic virus 1-associated myelopathy: a 14-year follow-up study. Arch Neurol 63(11):1560-1566. https://doi.org/10.1001/archneur.63.11.1560

Osame M, Usuku K, Izumo S, Ijichi N, Amitani H, Igata A et al (1986) HTLV-I associated myelopathy, a new clinical entity. Lancet 1(8488):1031-1032

Panfil AR, Al-Saleem JJ, Green PL (2013) Animal models utilized in HTLV-1 research. Virology (Auckl) 4:49-59. https://doi.org/10. 4137/VRT.S12140

Pessoa R, Watanabe JT, Nukui Y, Pereira J, Casseb J, de Oliveira AC et al (2014) Molecular characterization of human T-cell lymphotropic virus type 1 full and partial genomes by Illumina massively parallel sequencing technology. PLoS One 9(3):e93374. https://doi.org/10. 1371/journal.pone.0093374

Philip S, Zahoor MA, Zhi H, Ho YK, Giam CZ (2014) Regulation of human T-lymphotropic virus type I latency and reactivation by HBZ and Rex. PLoS Pathog 10(4):e1004040. https://doi.org/10.1371/ journal.ppat. 1004040

Poiesz BJ, Ruscetti FW, Gazdar AF, Bunn PA, Minna JD, Gallo RC (1980) Detection and isolation of type $C$ retrovirus particles from fresh and cultured lymphocytes of a patient with cutaneous T-cell lymphoma. Proc Natl Acad Sci U S A 77(12):7415-7419

Rende F, Cavallari I, Corradin A, Silic-Benussi M, Toulza F, Toffolo GM, Tanaka Y, Jacobson S, Taylor GP, D'Agostino DM, Bangham CRM, Ciminale V (2011) Kinetics and intracellular compartmentalization of HTLV-1 gene expression: nuclear retention of HBZ mRNAs. Blood 117(18):4855-4859. https://doi.org/ 10.1182/blood-2010-11-316463

Rosati E, Dowds CM, Liaskou E, Henriksen EKK, Karlsen TH, Franke A (2017) Overview of methodologies for T-cell receptor repertoire analysis. BMC Biotechnol 17(1):61. https://doi.org/10.1186/ s12896-017-0379-9

Rowan AG, Suemori K, Fujiwara H, Yasukawa M, Tanaka Y, Taylor GP, Bangham CRM (2014) Cytotoxic T lymphocyte lysis of HTLV-1 infected cells is limited by weak HBZ protein expression, but nonspecifically enhanced on induction of Tax expression. Retrovirology 11:116. https://doi.org/10.1186/s12977-014-0116-6

Rowan AG, Witkover A, Melamed A, Tanaka Y, Cook LBM, Fields P et al (2016) $\mathrm{T}$ cell receptor $\mathrm{V}$ beta staining identifies the malignant clone in adult $\mathrm{T}$ cell leukemia and reveals killing of leukemia cells by autologous CD8(+) T cells. Plos Pathogens 12(11). https://doi. org/10.1371/journal.ppat.1006030

Saito M (2019) Association between HTLV-1 genotypes and risk of HAM/TSP. Front Microbiol 10:1101. https://doi.org/10.3389/ fmicb.2019.01101

Saito M, Matsuzaki T, Satou Y, Yasunaga J, Saito K, Arimura K, Matsuoka M, Ohara Y (2009) In vivo expression of the HBZ gene of HTLV-1 correlates with proviral load, inflammatory markers and disease severity in HTLV-1 associated myelopathy/tropical spastic paraparesis (HAM/TSP). Retrovirology 6:19. https://doi.org/10. 1186/1742-4690-6-19

Saito M, Taylor GP, Saito A, Furukawa Y, Usuku K, Weber JN, Osame M, Bangham CRM (2001) In vivo selection of T-cell receptor junctional region sequences by HLA-A2 human T-cell lymphotropic virus type 1 Tax11-19 peptide complexes. J Virol 75(2):10651071. https://doi.org/10.1128/JVI.75.2.1065-1071.2001

Sato T, Coler-Reilly ALG, Yagishita N, Araya N, Inoue E, Furuta R, Watanabe T, Uchimaru K, Matsuoka M, Matsumoto N, Hasegawa Y, Yamano Y (2018) Mogamulizumab (anti-CCR4) in HTLV-1associated myelopathy. N Engl J Med 378(6):529-538. https://doi. org/10.1056/NEJMoa1704827

Satou Y, Miyazato P, Ishihara K, Yaguchi H, Melamed A, Miura M, Fukuda A, Nosaka K, Watanabe T, Rowan AG, Nakao M, Bangham CRM (2016) The retrovirus HTLV-1 inserts an ectopic CTCF-binding site into the human genome. Proc Natl Acad Sci U S A 113(11):3054-3059. https://doi.org/10.1073/pnas.1423199113

Satou Y, Yasunaga J, Yoshida M, Matsuoka M (2006) HTLV-I basic leucine zipper factor gene mRNA supports proliferation of adult $\mathrm{T}$ cell leukemia cells. Proc Natl Acad Sci U S A 103(3):720-725. https://doi.org/10.1073/pnas.0507631103

Satou Y, Yasunaga J, Zhao T, Yoshida M, Miyazato P, Takai K, Shimizu K, Ohshima K, Green PL, Ohkura N, Yamaguchi T, Ono M, Sakaguchi S, Matsuoka M (2011) HTLV-1 bZIP factor induces Tcell lymphoma and systemic inflammation in vivo. PLoS Pathog 7(2):e1001274. https://doi.org/10.1371/journal.ppat.1001274

Seegulam ME, Ratner L (2011) Integrase inhibitors effective against human T-cell leukemia virus type 1. Antimicrob Agents Chemother 55(5):2011-2017. https://doi.org/10.1128/AAC.01413-10

Suemori K, Fujiwara H, Ochi T, Ogawa T, Matsuoka M, Matsumoto T, Mesnard JM, Yasukawa M (2009) HBZ is an immunogenic protein, but not a target antigen for human T-cell leukemia virus type 1specific cytotoxic T lymphocytes. J Gen Virol 90(Pt 8):18061811. https://doi.org/10.1099/vir.0.010199-0

Sugata K, Yasunaga J, Kinosada H, Mitobe Y, Furuta R, Mahgoub M, Onishi C, Nakashima K, Ohshima K, Matsuoka M (2016) HTLV-1 viral factor HBZ induces CCR4 to promote T-cell migration and proliferation. Cancer Res 76(17):5068-5079. https://doi.org/10. 1158/0008-5472.CAN-16-0361

Tanaka A, Matsuoka M (2018) HTLV-1 alters T cells for viral persistence and transmission. Front Microbiol 9:461. https://doi.org/10.3389/ fmicb.2018.00461 
Taylor GP, Goon P, Furukawa Y, Green H, Barfield A, Mosley A, Nose H, Babiker A, Rudge P, Usuku K, Osame M, Bangham CRM, Weber JN (2006) Zidovudine plus lamivudine in human Tlymphotropic virus type-I-associated myelopathy: a randomised trial. Retrovirology 3:63. https://doi.org/10.1186/1742-4690-3-63

Uchiyama T, Yodoi J, Sagawa K, Takatsuki K, Uchino H (1977) Adult Tcell leukemia: clinical and hematologic features of 16 cases. Blood 50(3):481-492

Umehara F, Izumo S, Nakagawa M, Ronquillo AT, Takahashi K, Matsumuro K, Sato E, Osame M (1993) Immunocytochemical analysis of the cellular infiltrate in the spinal cord lesions in HTLV-Iassociated myelopathy. J Neuropathol Exp Neurol 52(4):424-430

Umehara F, Nakamura A, Izumo S, Kubota R, Ijichi S, Kashio N et al (1994) Apoptosis of T lymphocytes in the spinal cord lesions in HTLV-I-associated myelopathy: a possible mechanism to control viral infection in the central nervous system. J Neuropathol Exp Neurol 53(6):617-624. https://doi.org/10.1097/00005072199411000-00009

Yamamoto-Taguchi N, Satou Y, Miyazato P, Ohshima K, Nakagawa M, Katagiri K, Kinashi T, Matsuoka M (2013) HTLV-1 bZIP factor induces inflammation through labile Foxp3 expression. PLoS Pathog 9(9):e1003630. https://doi.org/10.1371/journal.ppat. 1003630

Yamano Y, Araya N, Sato T, Utsunomiya A, Azakami K, Hasegawa D, Izumi T, Fujita H, Aratani S, Yagishita N, Fujii R, Nishioka K, Jacobson S, Nakajima T (2009) Abnormally high levels of virusinfected IFN-gamma+ CCR4+ CD4+CD25+ T cells in a retrovirusassociated neuroinflammatory disorder. PLoS One 4(8):e6517. https://doi.org/10.1371/journal.pone.0006517

Yamano Y, Cohen CJ, Takenouchi N, Yao K, Tomaru U, Li HC, Reiter Y, Jacobson S (2004) Increased expression of human T lymphocyte virus type I (HTLV-I) Tax11-19 peptide-human histocompatibility leukocyte antigen $\mathrm{a} * 201$ complexes on CD4+ CD25+ T cells detected by peptide-specific, major histocompatibility complexrestricted antibodies in patients with HTLV-I-associated neurologic disease. J Exp Med 199(10):1367-1377. https://doi.org/10.1084/ jem. 20032042

Yamano Y, Coler-Reilly A (2017) HTLV-1 induces a Th1-like state in CD4(+)CCR4(+) T cells that produces an inflammatory positive feedback loop via astrocytes in HAM/TSP. J Neuroimmunol 304: 51-55. https://doi.org/10.1016/j.jneuroim.2016.08.012
Yamano Y, Nagai M, Brennan M, Mora CA, Soldan SS, Tomaru U, Takenouchi N, Izumo S, Osame M, Jacobson S (2002) Correlation of human T-cell lymphotropic virus type 1 (HTLV-1) mRNA with proviral DNA load, virus-specific CD8(+) T cells, and disease severity in HTLV-1-associated myelopathy (HAM/TSP). Blood 99(1):88-94

Yamano Y, Takenouchi N, Li HC, Tomaru U, Yao K, Grant CW, Maric DA, Jacobson S (2005) Virus-induced dysfunction of CD4+CD25+ $\mathrm{T}$ cells in patients with HTLV-I-associated neuroimmunological disease. J Clin Invest 115(5):1361-1368. https://doi.org/10.1172/ JCI23913

Yamauchi J, Coler-Reilly A, Sato T, Araya N, Yagishita N, Ando H, Kunitomo Y, Takahashi K, Tanaka Y, Shibagaki Y, Nishioka K, Nakajima T, Hasegawa Y, Utsunomiya A, Kimura K, Yamano Y (2015) Mogamulizumab, an anti-CCR4 antibody, targets human Tlymphotropic virus type 1 -infected CD8+ and CD4+ T cells to treat associated myelopathy. J Infect Dis 211(2):238-248. https://doi.org/ 10.1093/infdis/jiu438

Yasuma K, Matsuzaki T, Yamano Y, Takashima H, Matsuoka M, Saito M (2016a) HTLV-1 subgroups associated with the risk of HAM TSP are related to viral and host gene expression in peripheral blood mononuclear cells, independent of the transactivation functions of the viral factors. J Neuro-Oncol 22(4):416-430. https://doi.org/10. 1007/s13365-015-0407-2

Yasuma K, Yasunaga J, Takemoto K, Sugata K, Mitobe Y, Takenouchi N, Nakagawa M, Suzuki Y, Matsuoka M (2016b) HTLV-1 bZIP factor impairs anti-viral immunity by inducing co-inhibitory molecule, T cell immunoglobulin and ITIM domain (TIGIT). PLoS Pathog 12(1):e1005372. https://doi.org/10.1371/journal.ppat. 1005372

Yoshioka A, Hirose G, Ueda Y, Nishimura Y, Sakai K (1993) Neuropathological studies of the spinal cord in early stage HTLVI-associated myelopathy (HAM). J Neurol Neurosurg Psychiatry 56(9):1004-1007

Zhao T, Satou Y, Sugata K, Miyazato P, Green PL, Imamura T, Matsuoka M (2011) HTLV-1 bZIP factor enhances TGF-beta signaling through p300 coactivator. Blood 118(7):1865-1876. https:// doi.org/10.1182/blood-2010-12-326199

Publisher's note Springer Nature remains neutral with regard to jurisdictional claims in published maps and institutional affiliations. 